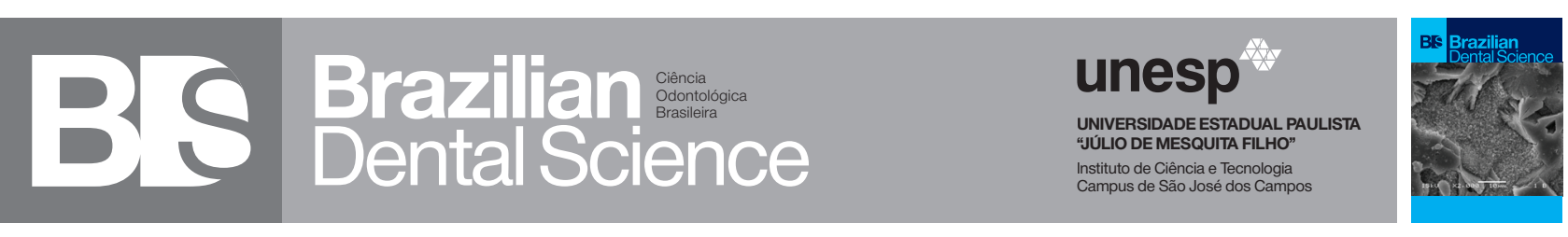

\title{
Methotrexate delayed wound healing of a pyogenic granuloma in a child with juvenile idiopathic arthritis
}

\author{
Metotrexato atrasou a cicatrização de um granuloma piogênico em criança com artrite idiopática juvenil \\ Lígia Ângelo Tavares SCHWARZMEIER ${ }^{1}$, Dárcio KITAKAWA ${ }^{2}$, Luiz Eduardo Blumer ROSA ${ }^{1}$, Luiz Antonio Guimarães CABRAL ${ }^{1}$, Janete \\ Dias ALMEIDA ${ }^{1}$ \\ 1 - Paulo State University (Unesp) - Institute of Science and Technology, São José dos Campos - Department of Biosciences and Diagnosis \\ - São José dos Campos - SP - Brazil. \\ 2 - City Hall of São Paulo and Suzano - Dentistry - CK Estomatologia - Suzano - SP - Brazil.
}

\begin{abstract}
A nine-year-old girl with of juvenile idiopathic arthritis (JIA) in use of methotrexate complained of a self-bleeding ulcerated lesion exhibiting a red surface in the lower lip. Pyogenic granuloma was confirmed by histopathological analysis. After the 7th and 15th days, the lip where biopsy had been done exhibited a deficient healing. The case was discussed with the physician for temporary suspension of methotrexate. Complete wound healing of the biopsied site occurred after temporary interruption of the medication. Wound healing after methotrexate temporary suspension allowed concluding that the drug delayed surgical wound healing was a consequence of drug cytotoxicity.
\end{abstract}

\section{KEYWORDS}

Arthritis, juvenile; granuloma, pyogenic; lip; methotrexate.

\section{RESUMO}

Uma menina de nove anos de idade com artrite idiopática juvenil (AIJ) em uso de metotrexato queixou-se de lesão ulcerada com sangramento espontâneo que exibia superfície avermelhada em lábio inferior. O granuloma piogênico foi confirmado pelo exame histopatológico. Após o $7^{\circ}$ e $15^{\circ}$ dias, a região do lábio onde a biópsia foi realizada exibiu cicatrização deficiente. $\mathrm{O}$ caso foi discutido com o médico e foi realizada a suspensão temporária do metotrexato que resultou em cicatrização completa. A cicatrização da ferida após a suspensão temporária do metotrexato permitiu concluir que o medicamento retardou a cicatrização da ferida cirúrgica como consequência da citotoxicidade da droga.

\section{PALAVRAS-CHAVE}

Artrite juvenil; granuloma piogênico; lábio; metotrexato.

\section{INTRODUCTION}

Tuvenile idiopathic arthritis (JIA) is the most common chronic rheumatic disease affecting children [1]. The disease causes a variety of symptoms, including: arthritis, fever and transient rash [2]. Symptoms are related to the breakdown of the innate immune mechanisms $[2,3,4]$. JIA treatments' main goals are pain and inflammation control. Corticoid and/or non-steroidal antiinflammatory drug administration are the primary treatment $[1,5]$. Methotrexate is a second line medication; it has many side effects, including oral ulcers $[1,6,7]$.

Pyogenic granuloma is an inflammatory reactive lesion that affects the conjunctive 
tissue. In the oral cavity, the site of involvement can be varied and patterned by many factors; it often involves the gingiva. It presents as a slow or fast growing lump and color dependents on the vascularity of the lesion $[8,9,10,11,12]$.

This is a case report of a patient affected by JIA treated with methotrexate, presenting pyogenic granuloma in lower lip. For the best of our knowledge other cases of pyogenic granuloma in patients with JIA in use of methotrexate have not been described in the literature.

\section{CASE REPORT}

A nine-year-old Asian girl with JIA treated with methotrexate presented ulcerated lesion in the lower lip. The lesion was nodular and circumscribed, exhibiting a red surface, covered by a thin white pseudomembrane, with spontaneous bleeding (Figure 1-a). Local dental trauma was observed due to nibbling habit. Excisional biopsy was performed (Figure 1-b) and histopathology showed benign proliferative lesion, constituted by an ulcerated surface covered by fibrinhemorrhagic exudate, and a highly vascular proliferation that resembled a granulation tissue, confirming the diagnosis of pyogenic granuloma (Figure 2).

After 15 days, a delay in wound healing was observed (Figure 1-c). Therefore, physician was contacted, and temporally suspension of the drug was made, culminating to complete wound healing of the biopsied site (Figure 1-d, e and f).
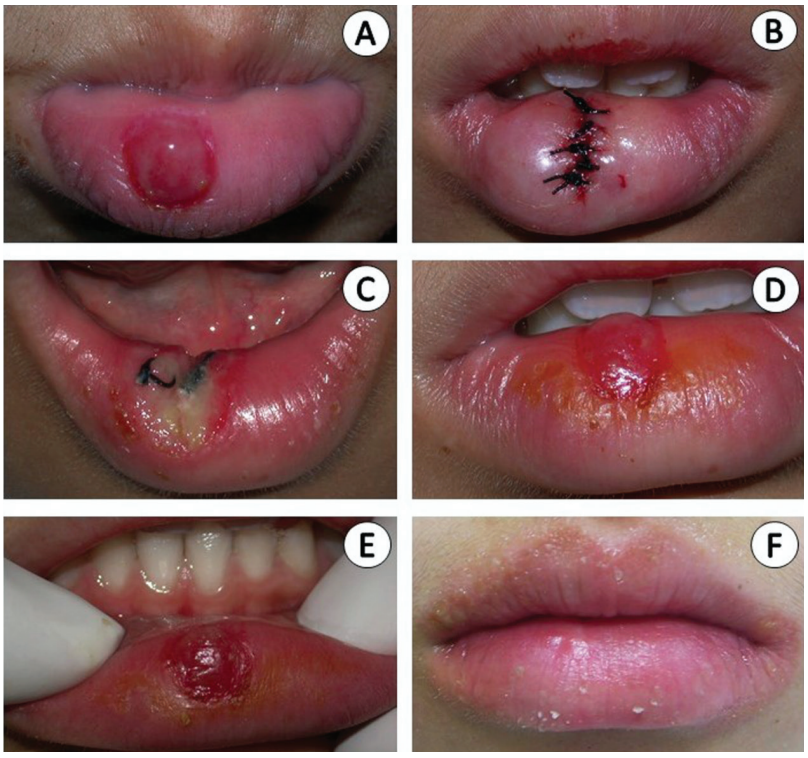

Figure 1 - Clinical presentation. a - Labial semi mucosa and mucosa - nodular well delimited sessile mass exhibiting atrophy on the surface. b - Suture after surgery. c - Fifteen days after biopsy - ulcer with delimited borders, showing tissue dilacerations, covered by serofibrinous membrane. Note the remaining suture in the superior portion of the ulcer. d - Twenty-one days after biopsy. e - Twenty-eight days after biopsy. $f$ - Complete healing after drug discontinuation.

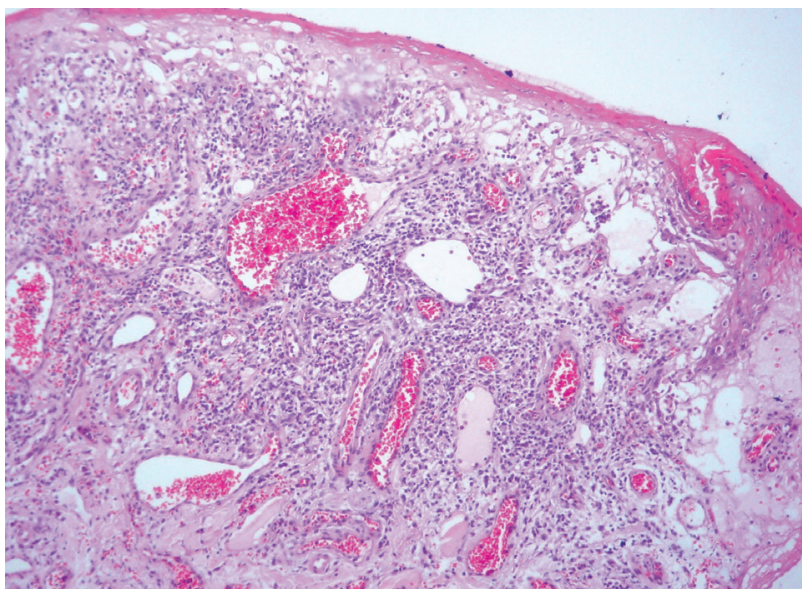

Figure 2 - Histopathology showed an ulcerated region covered by fibrin-hemorrhagic exudate exhibiting granulation tissue and numerous engorged capillary blood vessels spread in all regions of the slide (hematoxylin and eosin stain, 100x). 


\section{DISCUSSION}

Local trauma, evident as usual lip chewing, worsened by anterior diastema and bad oral hygiene practices were seen in our case. Association between chronic trauma and poor hygiene care is well established in literature as an etiological factor in pyogenic granuloma $[9,13]$.

The methotrexate is one of the drugs used for the treatment of JIA. This medicine may be given alone or in combination with other therapies. A prospective study of patterns of treatment for patients with JIA was performed by Davies et al. [14]. It was evaluated according to the type of initial presentation of pediatric reumatology considering the five groups: oligoarthritis (oJIA), polyarthritis (pJIA), systemic (sJIA), arthritis enthesitisrelated (ERA) and psoriatic arthritis (PsA). Considering the synthetic disease-modifying anti-rheumatic drugs (sDMARD), in the vast majority, methotrexate was prescribed to $35 \%$ of patients with oJIA, 94\% with pJIA, 93\% with sJIA, $74 \%$ with PsA and 56\% of ERA patients. In the overall assessment, sDMARD were used in 610 of 1051 patients evaluated, equivalent to $58 \%$.

Many adverse effects are attributed to anti-metabolic drugs $[6,15]$. Del Pozo et al. [16] described skin ulcers as consequence of methotrexate toxicity. Euvrard et al. [17] described a case of pyogenic granuloma in the lateral border of the tongue in a 12-yearold girl submitted to immunotherapy. These authors observed that adverse effects of the drug were related to patient age more than to the immunosuppression therapy period. In the same article, pyogenic granuloma was included as a side effect of immunosuppressive treatment, affecting $6.2 \%$ of children in therapy.

The methotrexate is an antimetabolic which may interfere in purine and pyrimidine formation, essential molecules in DNA synthesis and cell proliferation, interfering also in angiogenesis [7], both important events in healing process, and it should be emphasized the cytotoxic effect over oral mucosa cells [6]. Methotrexate induces the release of adenosine that participates in the mediation of several mechanisms such as the induction of apoptosis, anti-inflammatory action and immune response [18].

Oral ulcers are quite common in young patients submitted to methotrexate administration in therapeutic doses in rheumatic diseases [6]. It is an important side effect, because it is responsible for up to $10 \%$ of breaking treatment [7]. The cytotoxic effects of the drug are dose dependent and may also be associated with specific characteristics of each patient [19].

Methotrexate is also used as a chemotherapeutic drug. A study by Li et al. [20] evaluated the viscoelasticity of 4 types of cells (myoblasts and cell line fibroblasts from mice, lung cancer cells and embryonic kidney cells, both human) under the effect of methotrexate, and they found that the drug inhibited the proliferation of cells and, moreover, had no effect on cell viscosity, with decrease in relaxation times.

A study was conducted by Dojcinov et al. [21], in which 26 patients with mucocutaneous ulcerative lesions with Epstein Barr virus (EBV) and associated with different types of immunosuppression were evaluated. These patients used drugs to control immunosuppression, including azathioprine, methotrexate and cyclosporin-A. As occurred in our case, the study reports spontaneous remission of mucocutaneous ulcer after discontinuation of methotrexate for rheumatoid arthritis in an EBV-positive patient.

\section{CONCLUSION}

Wound healing after methotrexate temporary suspension allowed concluding that the drug delayed surgical wound healing was a consequence of drug cytotoxicity. 


\section{REFERENCES}

1. Weiss JE, llowite NT. Juvenile idiopathic arthritis. Rheum Dis Clin North Am. 2007 Aug;33(3):441-70, vi.

2. Gohar F, Kessel C, Lavric M, Holzinger D, Foell D. Review of biomarkers in systemic juvenile idiopathic arthritis: helpful tools or just playing tricks? Arthritis Res Ther.2016 Jul 13;18:163. doi: 10.1186/s13075-016-1069-z.

3. Martini A. It is time to rethink juvenile idiopathic arthritis classification and nomenclature. Ann Rheum Dis. 2012 Sep;71(9):1437-9. doi:10.1136/ annrheumdis-2012-201388. Epub 2012 Jun 7.

4. Gattorno M, Piccini A, Lasigliè D, Tassi S, Brisca G, Carta S, et al. The pattern of response to anti-interleukin-1 treatment distinguishes two subsets of patients with systemic-onset juvenile idiopathic arthritis. Arthritis Rheum. 2008 May;58(5):1505-15. doi: 10.1002/art.23437.

5. Ruperto N, Murray KJ, Gerloni V, WulffratN, de Oliveira SKF, Falcini F, etal. A randomized trial of parenteral methotrexate comparing an intermediate dose with a higher dose in children with juvenile idiopathic arthritis who failed to respond to standard doses of methotrexate. Arthritis Rheum. 2004;50:21912201.

6. Kalantzis A, Marshman Z,Falconer DT, Morgan PR, Odell EW. Oral effects of low-dose methotrexate treatment. Oral Surg Oral Med Oral Pathol Oral Radiol Endod 2005:100:52-62

7. Ranganath VK, FurstDE. Disease-modifying antirheumatic drug use in the elderly rheumatoid arthritis patients. Rheum Dis Clin N Am. 2007;33:197-217.

8. Jafarzadeh H, Sanatkhani M, Mohtasham N. Oral pyogenic granuloma: a review. J Oral Sci. 2006;48:167-75

9. Saravana GHL. Oral pyogenic granuloma: a review of 137 cases. Br J Oral Maxillofac Surg. 2009;47:318-319.

10. Gomes SR, Shakir QJ, Thaker PV, Tavadia JK. Pyogenic granuloma of the gingiva: a misnomer? A case report and review of literature. J Indian Soc Periodontol. 2013 Jul|;7(4):514-9. doi:10.4103/0972-124X.118327.
11. Sachdeva SK. Extragingival Pyogenic Granuloma: an Unusual Clinical Presentation. J Dent(Shiraz). 2015 Sep;16(3 Suppl):282-5.

12. Marla V, Shrestha A, GoelK, Shrestha S. The Histopathological Spectrum of Pyogenic Granuloma: aCase Series. Case Rep Dent. 2016;2016:1323798.

13. Angelopoulos AP.Pyogenic granuloma of the oral cavity: statistical analysis of its clinical features. J Oral Surg. 1971;29:840-847.

14. Davies R, Carrasco R, Foster HE, Baildam EM, Chieng SE, Davidson JE, etal. Treatment prescribing patterns in patients with juvenile idiopathic arthritis (JIA):Analysis from the UK Childhood Arthritis Prospective Study (CAPS). Semin Arthritis Rheum. 2016 0ct:46(2):190-5.

15. TackDA, Rogers RS III. Oral drug reactions. Dermatol Therapy 2002; 15:236250.

16. Del Pozo J, Martínez W, García-Silva J, Almagro M,Peña-Penabad C, Fonseca E. Cutaneous ulceration as a sign of methotrexate toxicity. Eur J Dermatol. 2001;11:450-452

17. Euvrard S, Kanitakis J, CochatP,Cambazard F, Claudy A. Skin diseases in children with organ transplants. J Am Acad Dermatol. 2001;:4:932-9.

18. Chan ES1, Cronstein BN. Molecular action of methotrexate in inflammatory diseases. Arthritis Res. 2002;4(4):266-73.

19. Souza CF, Suarez OM, Silva TF, Gorenstein AC, Quintella LP, Avelleira JC. Ulcerations due to methotrexate toxicity in a psoriasis patient. An Bras Dermatol. 2016 May-Jun;91(3):375-7.

20. LiM, Liu L, Xiao X, Xi N, Wang Y. Effects of methotrexate on the viscoelastic properties of single cells probed by atomic force microscopy.J Biol Phys. 2016 0ct:42(4):551-69.

21. Dojcinov SD, Venkataraman G, Raffeld M, Pittaluga S, Jaffe ES. EBV positive mucocutaneous ulcer--a study of 26 cases associated with various sources of immunosuppression. Am J Surg Pathol.2010 Mar;34(3):405-17.
Janete Dias Almeida

\section{(Corresponding address)}

Av. Eng. Francisco José Longo, 777, Jd São Dimas, 12245-

000, São José dos Campos, SP, Brasil.

e-mail: janete.almeida@unesp.br
Date submitted: 2019 Mar 14

Accept submission: 2019 Jul 10 